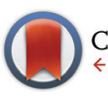

CrossMark \&lick for updates

Cite this: Org. Biomol. Chem., 2015, 13, 6977

Received 1st May 2015,

Accepted 14th May 2015

DOI: $10.1039 / \mathrm{c} 5 \mathrm{ob} 00884 \mathrm{k}$

www.rsc.org/obc

\section{meso-Tetraphenylporphyrin with a pi-system extended by fusion with anthraquinone $\uparrow$}

\author{
Mikhail A. Filatov, ${ }^{\text {a }}{ }^{a b}$ Ernesta Heinrich, ${ }^{a}$ Katharina Landfester ${ }^{a}$ and \\ Stanislav Baluschev ${ }^{a, c, d}$
}

Fusion with a 9,10-anthraquinone moiety was achieved to extend porphyrin's $\pi$-system. A bridged dihydroisoindole derivative was used to prepare the corresponding meso-tetraphenyltetraanthraquinonoporphyrin ( $\mathrm{Ph}_{4}$ TAQP) via a thermal retro-Diels-Alder reaction. The basic optical properties of the prepared new anthraquinonoporphyrin and its complexes with $\mathrm{Zn}$ and Pd were studied.

\section{Introduction}

Porphyrins with aromatic rings fused to the tetrapyrrolic core, so-called $\pi$-extended porphyrins, have attracted much attention in recent years as materials for numerous applications - from biomedical sensing and imaging to organic optoelectronics. ${ }^{1}$ Metallated $\pi$-extended porphyrins are particularly important for the process of triplet-triplet annihilation photon energy upconversion (TTA-UC). ${ }^{2}$ A variety of $\pi$-extended porphyrins have been synthesized by fusing benzene, ${ }^{3}$ naphthalene, ${ }^{4}$ pyrene, ${ }^{5}$ azulene, ${ }^{6}$ anthracene, ${ }^{7}$ corannulene, ${ }^{8}$ and other aromatic moieties to the meso- and $\beta$-positions of the macrocycle. Fusion of aromatic rings to all four pyrrole residues results in particularly strong effects on the $\pi$-system, leading to enhanced light absorption and efficient emission in the near-infrared (IR-A) region of the spectrum. ${ }^{9}$

First reported by Krautler and co-workers, a conjugation of naphthoquinone to a porphyrin has a remarkable effect on its properties. Particularly, resulting materials exhibit optical properties which resemble those of nanoscopic carbon materials with extended $\pi$-systems, such as graphene, graphite, and nanotubes. ${ }^{10}$ Theoretical studies of tetranaphthoquinonoporphyrin (TNQP) revealed that introduction of the carbonyl groups into the $\pi$-system results in strong alternations of bonds and a transformation of the conjugation from "benzene-type" to "butadiene-type". Unidirectional photon-

\footnotetext{
${ }^{a}$ Max Planck Institute for Polymer Research, Ackermannweg 10, D-55128 Mainz, Germany. Fax: +496131379100

${ }^{b}$ Institute of Polymers, Bulgarian Academy of Sciences, Acad. G. Bonchev Str., block 103-A, BG - 1113 Sofia, Bulgaria. E-mail: filatov@polymer.bas.bg

${ }^{c}$ Optics and Spectroscopy Department, Faculty of Physics, Sofia University

"St. Kliment Ochridski", 5 James Bourchier, 1164 Sofia, Bulgaria

${ }^{d}$ Freiburg Institute for Advanced Studies (FRIAS), Albert-Ludwigs-Universität

Freiburg, Albertstraße 19, D-79104 Freiburg, Germany

$\dagger$ Electronic supplementary information (ESI) available: NMR and mass-spectroscopy data. See DOI: $10.1039 / \mathrm{c} 5$ ob00884k
}

induced current associated with $\mathrm{p}-\pi$ conjugation enables lightharvesting efficiency of this kind of molecular skeleton to reach $90 \%$ in the range of $300-800 \mathrm{~nm} .{ }^{11}$ This makes TNQPs attractive materials for panchromatic dye-sensitized solar cells. Moreover, porphyrins fused with quinone moieties are expected to exhibit interesting electrochemical properties, since they are able to accept a load of at least 8 electrons per molecule. Such materials clearly promise to expand the range of multi-electron transfer (MET) catalysts - compounds having the ability to accommodate and transfer multiple electrons to reaction substrates at one time. ${ }^{12}$

Despite promising properties, tetraquinonoporphyrins (TQP) are almost unknown because the available synthetic methods in the field of $\pi$-extended porphyrins chemistry have been very limited until recently. To the best of our knowledge, the only representative of a porphyrin directly fused with four quinone fragments was obtained by Krautler and co-workers, using the $[4+2]$ cycloaddition reaction between $\beta, \beta^{\prime}$-tetrasulfolenoporphyrin $^{13}$ and an excess of benzoquinone. ${ }^{10}$

Herein we report a synthetic approach to meso-tetraphenyltetraanthraquinonoporphyrin $\left(\mathrm{Ph}_{4} \mathrm{TAQP}\right)$ based on a bridged dihydroisoindole precursor. In addition we describe the basic optical properties of the newly synthesized $\mathrm{Ph}_{4}$ TAQP free-base and its metal complexes.

\section{Results and discussion}

Due to the instability of isoindole and its $\pi$-expanded analogues, ${ }^{14}$ the formation of a fully conjugated $\pi$-system has to be performed after the formation of the porphyrin macrocycle. So far, two general synthetic methods have been employed to construct the extended porphyrin architecture: oxidative aromatization ${ }^{15}$ and thermal retro-Diels-Alder reaction. ${ }^{16}$

As is shown in Scheme 1, the use of the oxidative aromatization approach for the synthesis of tetraanthraquinono- 


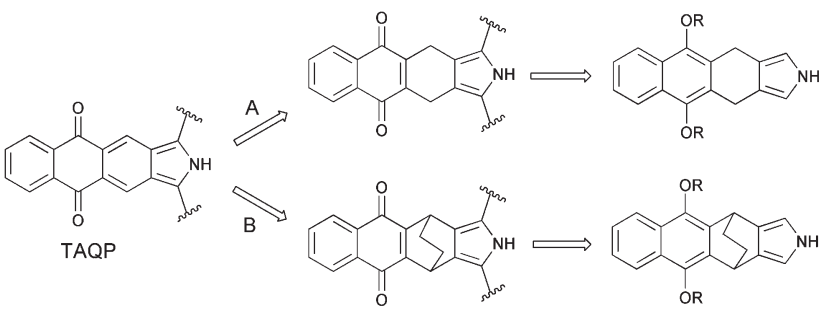

Scheme 1 Retrosynthetical analysis of a TAQP system.

porphyrin requires the corresponding dihydroisoindole derivative (Scheme 1, route A). According to the thermal retro-DielsAlder approach, the target molecule can be prepared from bicyclo[2.2.2] octadiene-annelated porphyrin which can undergo thermal extrusion of ethylene (route B).

A pyrrole derivative containing a naphthoquinone moiety represents a direct precursor for the synthesis of TAQP through route A. We first examined the possibility to apply directly 1,4,4a,9a-tetrahydro-anthraquinone 1 (Scheme 2) for the synthesis of the corresponding pyrrole from vinyl or allyl sulfones via a Barton-Zard reaction. ${ }^{17}$ Treatment of 1 with $\mathrm{PhSCl}$, followed by oxidation with Oxone led to the chlorosulfone derivative 2. Further reaction with DBU yielded 2-phenylsulfonylanthraquinone 3 , rather than the expected vinyl sulfone. An attempt to introduce 3 into Barton-Zard synthesis was unsuccessful and delivered mixture of products arising from the reduction of the quinone moiety. Thus, a protection of the reactive quinonic moiety was necessary to avoid side reactions during the pyrrole synthesis. Conversion of the quinone into corresponding hydroquinone diacetates was preferable over reductive methylation since it requires mild conditions for further deprotection. ${ }^{18}$

Dione $\mathbf{1}$ is known to form a deprotonated dihydronaphthoquinone irreversibly upon treatment with bases. ${ }^{7}$ Treatment of 1 with DBU and acetic anhydride provided diacetate 4. It should be noted that this procedure was found to give higher yields than previously reported aromatization of the dione ring by boiling with acetic anhydride and acetic acid in the presence of $p$-toluenesulfonic acid as a catalyst. ${ }^{19}$

Diacetate was then used for the preparation of allylsulfone 5, employing a previously established procedure. As expected, compound $\mathbf{5}$ was formed in good yield. However, under the conditions of Barton-Zard reaction ( $t$-BuOK, THF, isocyanoacetate) ${ }^{20}$ no formation of the corresponding pyrrole compound was observed. Diacetoxyanthracene 6 was the only isolated product. Attempts to optimize the reaction conditions: changing the base (DBU, potassium and sodium tertbutoxides, HMDS), solvents and temperature regimes failed to deliver the target product. It is known that aromatization of cyclohexadienes can be incurred by strong bases. ${ }^{21}$ However, taking into account that a similar sulfone derivative containing butoxy-groups instead or acetoxy-groups was previously successfully used in the pyrrole synthesis, ${ }^{7}$ it is interesting that sulfone 6 behaves so differently under basic conditions, when elimination is the predominant pathway.

Thus we focused further efforts on the thermal retro-DielsAlder approach. 1,4-Naphthoquinone was reacted with 1,3cyclohexadiene to obtain dione precursor 7 . Its acetylation gave 8, which was used for the preparation of the corresponding sulfone 9. As expected, the Barton-Zard reaction with isocyanoacetate synthesis delivered pyrrole $\mathbf{1 0}$.

In this case tert-butyl isocyanoacetate ${ }^{24}$ was used, since for pyrrole tert-butyl esters a decarboxylation reaction can be performed via solvolysis in neat trifluoroacetic acid. These conditions were expected to secure the hydroquinone moiety from deprotection. Indeed, treatment with TFA for 30 min delivered pyrrole 11 in good yield (68\%).

With pyrrole 11 in hand, we succeeded to prepare intermediate porphyrin $\mathbf{1 2}$ according to the conventional Lindsey condensation. ${ }^{22}$ As shown in Scheme 3, pyrrole $\mathbf{1 1}$ reacted with benzaldehyde in $\mathrm{CH}_{2} \mathrm{Cl}_{2}$ in the presence of $\mathrm{BF}_{3} \cdot \mathrm{OEt}_{2}$, followed by oxidation with 2,3-dichloro-5,6-dicyanobenzoquinone

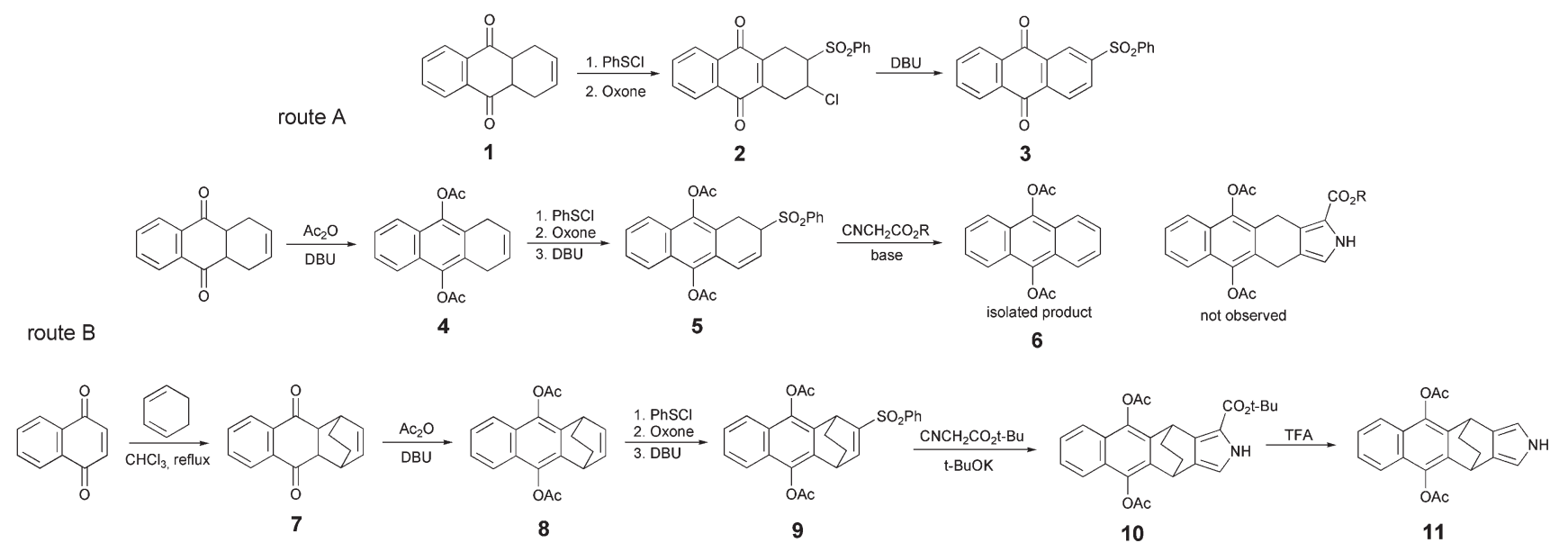

Scheme 2 Synthesis of a TAQP pyrrole precursor. 


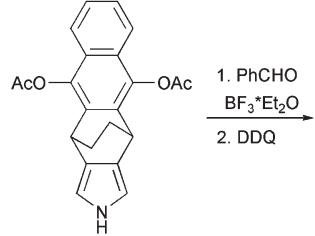

11
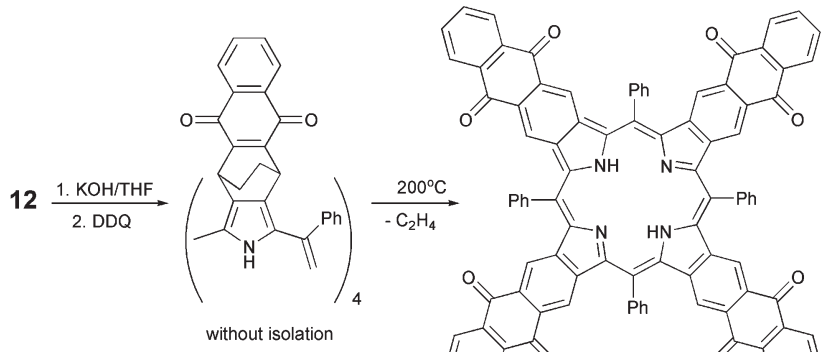
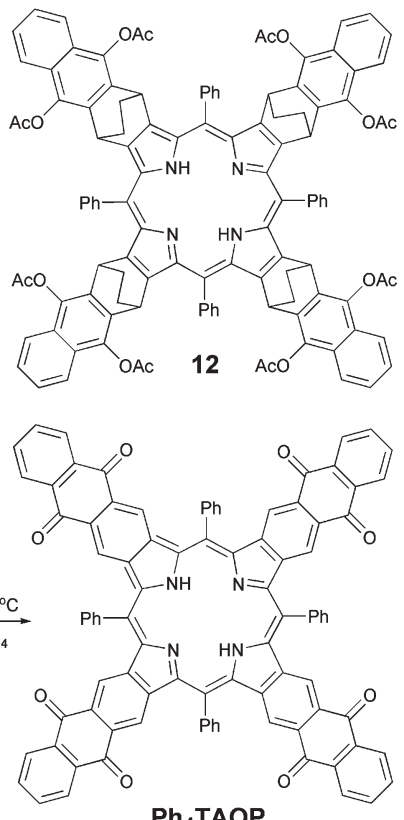

$\mathrm{Ph}_{4}$ TAQP

Scheme 3 Synthesis of $\mathrm{Ph}_{4}$ TAQP.

(DDQ) at room temperature for additional 3 hours to afford porphyrin 12 in $18 \%$ yield after purification. After further treatment of the obtained porphyrin $\mathbf{1 2}$ with $\mathrm{KOH}$ and oxidation by DDQ the resulting crude intermediate was heated at $200{ }^{\circ} \mathrm{C}$ in vacuum for $4 \mathrm{~h}$. Target tetraanthraquinonoporphyrin was isolated in $65 \%$ yield after chromatographic purification and recrystallization. To our surprise, instead of the expected problems with poor solubility due to $\pi$-stacking, we observed a rather good solubility (as compared to tetranaphtho- or tetraanthraporphyrins) of the obtained product in common organic solvents (chlorohydrocarbons, aromatics, THF).

The aromatization was clearly observed by the disappearance of methylene groups and the appearance of a new singlet peak in the aromatic region corresponding to eight protons on the anthraquinone rings in the ${ }^{1} \mathrm{H}$ NMR spectrum. It is noteworthy that well-resolved ${ }^{1} \mathrm{H}$ and ${ }^{13} \mathrm{C}$ NMR spectra were obtained after addition of trifluoroacetic acid (TFA) which converted the porphyrin into a dication form. MALDI-TOF mass spectra gave the additional evidence for the formation of $\mathrm{Ph}_{4}$ TAQP (ESI $\dagger$ ).

The absorption and emission spectra of porphyrins 12, $\mathrm{Ph}_{4} \mathrm{TAQP}$ and its metal complexes are compared in Fig. 1. Electronic absorption spectra of $\mathbf{1 2}$ are similar to other tetratetraphenyl- $\beta$-octaalkylporphyrins, such as the derivatives of octaethylporphyrin (OEP) showing a Soret band at $434 \mathrm{~nm}$ and Q-bands at 523, 607, $675 \mathrm{~nm}$ in $\mathrm{CH}_{2} \mathrm{Cl}_{2}$ (for comparison, tetraphenyltetracyclohexenoporphyrin free base: Soret band $439 \mathrm{~nm}, \mathrm{Q}$-bands 537, 580, 606, $674 \mathrm{~nm}) .^{20}$ The fluorescence spectrum of $\mathbf{1 2}$ is also consistent with this type of porphyrin skeleton, showing a maximum at $718 \mathrm{~nm}$ and a low quantum yield of emission $\left(\varphi_{\mathrm{fl}}<0.01\right.$ in toluene, $\left.\lambda_{\mathrm{exc}}=638 \mathrm{~nm}\right)$.

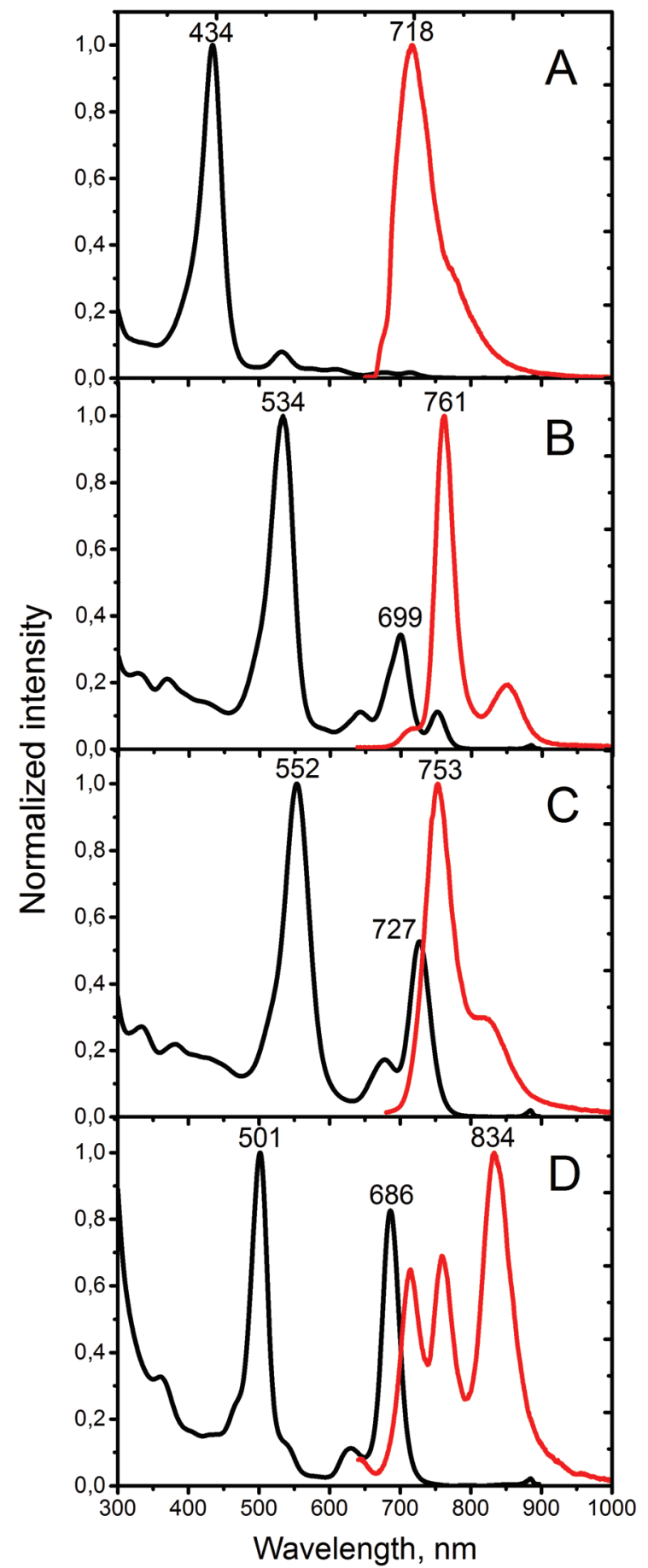

Fig. 1 Absorption (black) and emission (red lines) of (A) porphyrin 12, (B) $\mathrm{Ph}_{4} T A Q P$ free base, (C) $\mathrm{Ph}_{4} T A Q P-Z n$, and (D) $\mathrm{Ph}_{4} T A Q P-P d$. Solvent: toluene.

$\mathrm{Ph}_{4} \mathrm{TAQP}$ exhibits strongly red-shifted Soret and Q-bands (Fig. 1B). The vibronic structure in the Q-band region is wellresolved. The lowest energy Q-band $(752 \mathrm{~nm})$ is red-shifted by $77 \mathrm{~nm}$ relative to the corresponding transition of the porphyrin 12 due to the effect of extended $\pi$-conjugation. At the same time, intensification of Q-bands is taking place - the 


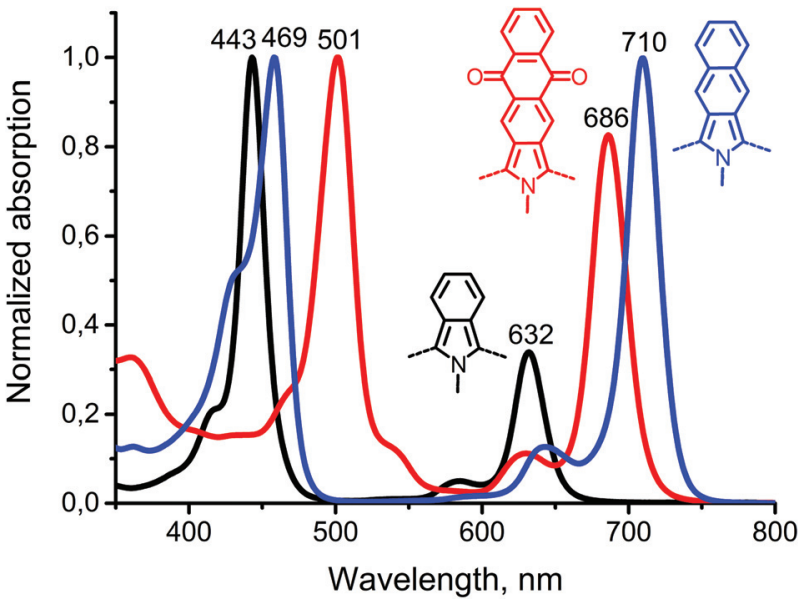

Fig. 2 UV-Vis absorption spectra of $\mathrm{Ph}_{4}$ TBPPd (black), $\mathrm{Ph}_{4}$ TAQPPd (red) and $\mathrm{Ph}_{4}$ TNPPd (blue).

maximum absorption ratio of the Q-band to the Soret band is enhanced from 0.09 (in 12) to 0.35 . The free-base shows much stronger emission $\left(\varphi_{\mathrm{fl}}=0.08\right)$ than the parent compound 12, with a small Stokes shift $(9 \mathrm{~nm})$. Metal insertion has a profound effect on optical properties. The absorption spectra of $\mathrm{Zn}$ and Pd-complexes are shown in Fig. 1C and D. Very strong blue-shift by $66 \mathrm{~nm}$ upon palladium insertion and $25 \mathrm{~nm}$ upon zinc insertion are observed for the lowest energy Q-band. Both complexes show relatively strong emission $\left(\varphi_{\mathrm{em}}=0.11\right.$ and 0.06 for $\mathrm{Zn}$ and Pd-complexes respectively). The emission of $\mathrm{Ph}_{4} \mathrm{TAQP}$ shows multiple maxima that may be associated either with excimer formation or formation of charge-transfer excited states. Solutions of $\mathrm{Ph}_{4} \mathrm{TAQP}$ and its metal complexes do not decompose noticeably when exposed to daylight for several days, indicating good photostability compared to other $\pi$-extended porphyrins. ${ }^{23}$

Comparison of the absorption spectra of $\mathrm{Ph}_{4}$ TAQPPd with those of palladium(II) tetraphenyltetrabenzo- and tetraphenyltetranaphthoporphyrins $\left(\mathrm{Ph}_{4} \mathrm{TBPPd}\right.$ and $\mathrm{Ph}_{4} \mathrm{TNPPd}$ respectively, Fig. 2) demonstrates the effect of anthraquinone fusion on the porphyrin core with respect to annelation of extra benzo-rings. The strong effect on the energies of $S_{1}$ and $S_{2}$ states of the molecule is manifested by the pronounced red shift of the Soret and Q-bands. While in the case of $\mathrm{Ph}_{4} \mathrm{TBPPd}$ and $\mathrm{Ph}_{4}$ TNPPd the Soret band is shifted only by $20-30 \mathrm{~nm}$ with respect to parent palladium(II) tetraphenylporphyrin, fusion of anthracenes causes $100 \mathrm{~nm}$ red shift. Nevertheless, a "spectral window" between the Soret and Q-bands allows for the application of $\mathrm{Ph}_{4}$ TAQPPd as a sensitizer for the TTA-UC process that will be reported in a separate study.

\section{Conclusions}

Two approaches towards the synthesis of TAQP were explored: the one based on the hydroisoindole precursor and bridged dihydroisoindole. The latter was found to be suitable for the synthesis of a target compound using the Barton-Zard reaction. The strategy based on oxidative aromatization of the dihydroisoindole precursor failed to deliver the target compound due to side reactions in the course of pyrrole synthesis. The optical properties of $\mathrm{Ph}_{4} \mathrm{TAQP}$ indicate electronic features that call for theoretical studies, as well as for better characterization using photophysical and electrochemical experiments. Indeed, new quinonoporphyrins are expected to exhibit interesting electrochemical properties as a result of the directly conjugated porphyrin and quinone moieties. Such materials appear to be of interest in photon energy conversion systems and in other applications. We relay a detailed discussion of the photophysical properties of variously substituted TAQP for a separate study.

\section{Experimental}

1,4,4a,9a-Tetrahydroanthraquinone ${ }^{7}$ and tert-butyl isocyanoacetate $^{24}$ were prepared according to published synthetic protocols. DBU, thiophenol, bis(benzonitrile)palladium(II) chloride, DDQ, N-chlorosuccinimide, Oxone, 1,4-naphthoquinone, trifluoroacetic acid, benzaldehyde, boron trifluoride etherate and extra dry THF were purchased from SigmaAldrich. The handling of all air/water sensitive materials was carried out using standard high vacuum techniques. All solvents and reagents were obtained from commercial sources and used as received. Where mixtures of solvents were used, ratios are reported by volume. Column chromatography was carried out on silica gel 60 at normal pressure. NMR spectra were recorded on Bruker DPX 250, Bruker AC300 NMR and Bruker Avance 500 spectrometers, with the solvent proton or carbon signal as an internal standard. Elemental analysis was carried out using a Foss Heraeus Vario EL. Electronic absorption spectra were recorded on a Perkin Elmer Lambda 25 instrument. MALDI-TOF spectra were recorded on a Bruker Reflex spectrometer III instrument using dithranol as a matrix. Melting points were determined on a Büchi hot stage apparatus and are uncorrected. Emission spectra were recorded using a Fluoromax-2 instrument. Emission quantum yields of the compounds were measured relative to the fluorescence of free-base tetraphenylporphyrin $\left(\varphi_{\mathrm{fl}}=0.11\right)^{25}$ in deoxygenated toluene.

2-Benzenesulfonyl-3-chloro-1,2,3,4-tetrahydro-anthra-quinone 2

${ }^{1} \mathrm{H}$ NMR $\delta_{\mathrm{H}}\left(300 \mathrm{MHz}, \mathrm{CD}_{2} \mathrm{Cl}_{2}\right) 8.06(2 \mathrm{H}, \mathrm{m}), 7.97(2 \mathrm{H}, \mathrm{m})$, 7.79-7.59 (5H, m), $5.03(1 \mathrm{H}, \mathrm{q}, J=3.3 \mathrm{~Hz}), 4.05(1 \mathrm{H}, \mathrm{m})$, 3.42-2.92 (4H, m). ${ }^{13} \mathrm{C}$ NMR $\delta_{\mathrm{C}}\left(75 \mathrm{MHz}, \mathrm{CD}_{2} \mathrm{Cl}_{2}\right)$ 184.04, $140.57,140.45,139.49,135.24,134.59,134.56,133.21,130.52$, 129.97, 127.01, 126.94, 62.80, 51.53, 30.72, 20.30. Anal. calcd for $\mathrm{C}_{20} \mathrm{H}_{17} \mathrm{ClO}_{4} \mathrm{~S}$ : C, 61.77; H, 4.41; found: C, 61.23; H, 4.65.

\section{2-Benzenesulfonyl-anthraquinone 3}

${ }^{1} \mathrm{H}$ NMR $\delta_{\mathrm{H}}\left(300 \mathrm{MHz}, \mathrm{CD}_{2} \mathrm{Cl}_{2}\right) 8.76(1 \mathrm{H}, \mathrm{t}, J=1.2 \mathrm{~Hz}), 8.4(2 \mathrm{H}$, $\mathrm{t}, J=1.1 \mathrm{~Hz}), 8.28(2 \mathrm{H}, \mathrm{m}), 8.09-8.03(2 \mathrm{H}, \mathrm{m}), 7.90-7.82(2 \mathrm{H}$, $\mathrm{m}), 7.64-7.53(2 \mathrm{H}, \mathrm{m}) .{ }^{13} \mathrm{C}$ NMR $\delta_{\mathrm{C}}\left(75 \mathrm{MHz}, \mathrm{CD}_{2} \mathrm{Cl}_{2}\right)$ 182.06, 
148.44, 142.38, 137.36, 135.57, 135.41, 135.37, 134.94, 134.73, 134.61, 134.57, 133.18, 130.62, 129.26, 129.16, 128.02, 127.05. Anal. calcd for $\mathrm{C}_{20} \mathrm{H}_{12} \mathrm{O}_{4} \mathrm{~S}$ : C, 68.95; H, 3.47; found: C, 68.32; $\mathrm{H}, 3.72$.

\section{9,10-Diacetoxy-1,4-dihydro-anthracene 4}

The title compound was prepared following a modified literature procedure. $^{26}$ 1,8-Diazabicycloundec-7-ene $(10.5 \mathrm{~mL}$, $70 \mathrm{mmol}$ ) was added to a stirred solution of 1,4,4a,9a-tetrahydroanthraquinone $(6.36 \mathrm{~g}, 30 \mathrm{mmol})$ and THF $(100 \mathrm{~mL})$ at room temperature. The mixture was cooled in an ice bath and acetic anhydride $(8.5 \mathrm{~mL}, 90 \mathrm{mmol})$ was added dropwise over a period of $10 \mathrm{~min}$ and the resulting solution was stirred for 2 hours. Then diethyl ether $(100 \mathrm{~mL})$ was added to precipitate the product. The solid so formed was filtered and washed with ether $(50 \mathrm{~mL})$ to give $8.44 \mathrm{~g}(95 \%)$ of the product as a white powder (m.p. 255-257 ${ }^{\circ} \mathrm{C}$, lit. 256-258 $\left.{ }^{\circ} \mathrm{C}\right) .{ }^{26} \quad{ }^{1} \mathrm{H} \quad \mathrm{NMR}$ $\delta_{\mathrm{H}}\left(300 \mathrm{MHz}, \mathrm{CD}_{2} \mathrm{Cl}_{2}\right) 7.75(2 \mathrm{H}, \mathrm{m}), 7.51(2 \mathrm{H}, \mathrm{m}), 5.95(2 \mathrm{H}, \mathrm{m})$, $3.37\left(4 \mathrm{H}\right.$, br. s), 2.49 (6H, s). ${ }^{13} \mathrm{C} \mathrm{NMR} \delta_{\mathrm{C}}\left(75 \mathrm{MHz}, \mathrm{CD}_{2} \mathrm{Cl}_{2}\right)$ $169.57,142.2,126.97,126.52$, 125.59, 123.54, 121.62, 25.0, 20.96.

\section{9,10-Diacetoxy-2-benzenesulfonyl-1,2-dihydro-anthracene 5}

The title compound was prepared following a modified literature procedure. ${ }^{27}$ Thiophenol ( $2 \mathrm{~mL}, 2.2 \mathrm{~g}, 20 \mathrm{mmol}$ ) was added dropwise to a suspension of $\mathrm{N}$-chlorosuccinimide (2.67 $\mathrm{g}, 20 \mathrm{mmol})$ in $\mathrm{CH}_{2} \mathrm{Cl}_{2}(20 \mathrm{~mL})$ under cooling in an ice bath. The mixture was stirred for $1 \mathrm{~h}$ at r.t. and the resulting orange solution was added dropwise to a stirred solution of 9,10-diacetoxy-1,4-dihydro-anthracene $(5.92 \mathrm{~g}, 20 \mathrm{mmol})$ in $\mathrm{CH}_{2} \mathrm{Cl}_{2}(150 \mathrm{~mL})$ at $0{ }^{\circ} \mathrm{C}$. The mixture was stirred at room temperature for $2 \mathrm{~h}$ and then evaporated in a vacuum. The residue was dissolved in methanol $(60 \mathrm{~mL})$ and a suspension of Oxone $(12.3 \mathrm{~g}, 20 \mathrm{mmol})$ in water $(30 \mathrm{~mL})$ was added under vigorous stirring. The mixture was stirred at room temperature for 2 days, diluted with water $(100 \mathrm{~mL})$ and extracted with $\mathrm{CH}_{2} \mathrm{Cl}_{2}$. The combined organic layers were dried with $\mathrm{Na}_{2} \mathrm{SO}_{4}$ and evaporated to dryness. The resulting solid was dissolved in $\mathrm{CH}_{2} \mathrm{Cl}_{2}(50 \mathrm{~mL})$, and $\mathrm{DBU}(3 \mathrm{~mL}, 20 \mathrm{mmol})$ was added dropwise over a period of $10 \mathrm{~min}$ at $0{ }^{\circ} \mathrm{C}$. The mixture was stirred for $1 \mathrm{~h}$ at room temperature, washed with water, dried with $\mathrm{Na}_{2} \mathrm{SO}_{4}$ and evaporated in a vacuum. The solid residue was recrystallized from $\mathrm{MeOH}$ to give $6.1 \mathrm{~g}$ (70\%) of the title compound as a white powder (m.p. 155-157 $\left.{ }^{\circ} \mathrm{C}\right) .{ }^{1} \mathrm{H}$ NMR $\delta_{\mathrm{H}}\left(300 \mathrm{MHz}, \mathrm{CD}_{2} \mathrm{Cl}_{2}\right) 7.69(4 \mathrm{H}, \mathrm{m}), 7.51(2 \mathrm{H}, \mathrm{m}), 7.3(3 \mathrm{H}, \mathrm{d}$, $J=6.9 \mathrm{~Hz}), 6.84(1 \mathrm{H}, \mathrm{dd}, J=9.9 \mathrm{~Hz}), 6.18(1 \mathrm{H}, \mathrm{dd}, J=9.9 \mathrm{~Hz})$, $4.09(1 \mathrm{H}, \mathrm{m}), 3.48(1 \mathrm{H}, \mathrm{m}), 3.11(1 \mathrm{H}, \mathrm{m}), 2.49(3 \mathrm{H}, \mathrm{s}), 2.46(3 \mathrm{H}$, s). ${ }^{13} \mathrm{C}$ NMR $\delta_{\mathrm{C}}\left(75 \mathrm{MHz}, \mathrm{CD}_{2} \mathrm{Cl}_{2}\right) 169.17,136.76,134.33$, $129.88,129.11,128.06,128.0,127.54,127.43$, 127.06, 122.41, $122.09,121.85,121.72,121.51,23.1,20.93$. Anal. calcd for $\mathrm{C}_{24} \mathrm{H}_{20} \mathrm{O}_{6} \mathrm{~S}$ : C, 66.04; H, 4.62; found: C, 66.32; H, 4.85 .

\section{1,2,3,4,4a,9a-Hexahydro-1,4-etheno-anthraquinone 7}

A mixture of 1,4-naphthoquinone (10 g, $63 \mathrm{mmol}), 1,3$-cyclohexadiene (9.5 mL, $100 \mathrm{mmol})$ and 2,6-di-tert-butylphenol (0.05 g, $0.24 \mathrm{mmol}$ ) was dissolved in $\mathrm{CHCl}_{3}$ and refluxed for
$24 \mathrm{~h}$ under argon. The resulting mixture was evaporated in a vacuum and the residue was recrystallized from EtOH to give $12.7 \mathrm{~g}(85 \%)$ of the title compound as a white powder (m.p. 83-85 $\left.{ }^{\circ} \mathrm{C}\right) .{ }^{1} \mathrm{H}$ NMR $\delta_{\mathrm{H}}\left(300 \mathrm{MHz}, \mathrm{CD}_{2} \mathrm{Cl}_{2}\right) 7.98(2 \mathrm{H}, \mathrm{m})$, $7.69(2 \mathrm{H}, \mathrm{m}), 6.13(2 \mathrm{H}, \mathrm{m}), 3.3(2 \mathrm{H}, \mathrm{m}), 3.21(2 \mathrm{H}, \mathrm{t}, J=1.3 \mathrm{~Hz})$, $1.78(2 \mathrm{H}, \mathrm{m}), 1.38(2 \mathrm{H}, \mathrm{m}) .{ }^{13} \mathrm{C} \mathrm{NMR} \delta_{\mathrm{C}}\left(75 \mathrm{MHz}, \mathrm{CD}_{2} \mathrm{Cl}_{2}\right)$ 198.12, 181.74, 151.07, 136.28, 134.47, 134.33, 134.24, 133.83, 133.0, 127.14, 126.59, 50.99, 36.26, 34.72, 25.44, 25.11. Anal. calcd C, 80.65; H, 5.92; O, 13.43; found: C, 80.12; H, 6.04.

\section{9,10-Acetoxy-1,2,3,4-tetrahydro-1,4-etheno-anthracene 8}

The title compound was obtained according to the procedure described for 4. Yield: 90\%. White powder with m.p. $232-233{ }^{\circ} \mathrm{C} .{ }^{1} \mathrm{H}$ NMR $\delta_{\mathrm{H}}\left(300 \mathrm{MHz}, \mathrm{CD}_{2} \mathrm{Cl}_{2}\right) 7.8(2 \mathrm{H}, \mathrm{m})$, $7.5(2 \mathrm{H}, \mathrm{m}), 6.55(2 \mathrm{H}, \mathrm{m}), 4.08(2 \mathrm{H}, \mathrm{m}), 2.52(2 \mathrm{H}, \mathrm{m}), 1.58(4 \mathrm{H}$, s). ${ }^{13} \mathrm{C}$ NMR $\delta_{\mathrm{C}}\left(75 \mathrm{MHz}, \mathrm{CD}_{2} \mathrm{Cl}_{2}\right) 170.01,137.63,135.28$, 134.36, 126.61, 126.37, 121.80, 34.95, 24.94, 21.03. Anal. calcd for $\mathrm{C}_{20} \mathrm{H}_{18} \mathrm{O}_{4}$ : C, 74.52; H, 5.63; found: C, 74.87; H, 5.85 .

\section{9,10-Diacetoxy-12-benzenesulfonyl-1,2,3,4-tetrahydro-1,4- etheno-anthracene 9}

The title compound was obtained according to the procedure described for 5. Yield: 65\%. White powder with m.p. $213-214{ }^{\circ} \mathrm{C} .{ }^{1} \mathrm{H}$ NMR $\delta_{\mathrm{H}}\left(300 \mathrm{MHz}, \mathrm{CD}_{2} \mathrm{Cl}_{2}\right) 7.81(3 \mathrm{H}, \mathrm{m})$, $7.69(1 \mathrm{H}, \mathrm{m}), 7.62(1 \mathrm{H}, \mathrm{m}), 7.51(5 \mathrm{H}, \mathrm{m}), 4.34(2 \mathrm{H}, \mathrm{m}), 2.52$ $(3 \mathrm{H}, \mathrm{s}), 2.42(3 \mathrm{H}, \mathrm{s}), 1.65(4 \mathrm{H}, \mathrm{m}) .{ }^{13} \mathrm{C}$ NMR $\delta_{\mathrm{C}}(75 \mathrm{MHz}$, $\left.\mathrm{CD}_{2} \mathrm{Cl}_{2}\right)$ 169.80, 169.50, 147.74, 144.23, 139.86, 138.46, 138.14, $134.08,131.21,131.18,129.84,128.32,127.23,127.15,126.75$, 126.56, 122.06, 121.93, 36.5, 35.59, 25.60, 24.81, 21.0, 20.86. Anal. calcd for $\mathrm{C}_{26} \mathrm{H}_{22} \mathrm{O}_{6} \mathrm{~S}$ : C, 67.52; H, 4.79; found: C, 67.89; H, 5.04.

\section{5,10-Diacetoxy-4,11-etheno- $2 \mathrm{H}$-naphtho[2,3-f]isoindole- 1-carboxylic acid tert-butyl ester 10}

The title compound was obtained according to a previously published general procedure. ${ }^{24}$ Yield: $78 \%$. White powder with m.p. $186-187{ }^{\circ} \mathrm{C} .{ }^{1} \mathrm{H}$ NMR $\delta_{\mathrm{H}}\left(300 \mathrm{MHz}, \mathrm{CD}_{2} \mathrm{Cl}_{2}\right) 8.62(1 \mathrm{H}, \mathrm{br}$. s), $7.78(2 \mathrm{H}, \mathrm{m}), 7.5(2 \mathrm{H}, \mathrm{m}), 6.7(1 \mathrm{H}, \mathrm{d}, J=2.7 \mathrm{~Hz}), 4.93(1 \mathrm{H}$, m), $4.42(1 \mathrm{H}, \mathrm{m}), 2.54(3 \mathrm{H}, \mathrm{s}), 2.53(3 \mathrm{H}, \mathrm{s}), 1.77(4 \mathrm{H}, \mathrm{m}), 1.61$ (9H, s). ${ }^{13} \mathrm{C}$ NMR $\delta_{\mathrm{C}}\left(75 \mathrm{MHz}, \mathrm{CD}_{2} \mathrm{Cl}_{2}\right) 169.93,169.87,161.40$, $138.45,137.96,134.75,134.21,132.88,129.02$, 126.83, 126.56, $126.55,121.86,117.12$, 114.22, 81.06, 32.54, 32.29, 28.84, 28.51, 27.20, 26.59, 21.14, 21.06. Anal. calcd for $\mathrm{C}_{27} \mathrm{H}_{27} \mathrm{NO}_{6}$ : C, 70.27; H, 5.90; N, 3.03; found: C, 69.89; H, 6.14; N, 2.87.

\section{5,10-Diacetoxy-4,11-etheno-2H-naphtho[2,3-f]isoindole 11}

Compound 10 (1 g, $2.2 \mathrm{mmol})$ was dissolved in TFA $(30 \mathrm{~mL})$, and the solution was stirred for $30 \mathrm{~min}$ under $\mathrm{Ar}$ at room temperature. After the addition of $\mathrm{CH}_{2} \mathrm{Cl}_{2}(50 \mathrm{~mL})$, the mixture was washed with water, then with $10 \%$ solution of $\mathrm{Na}_{2} \mathrm{CO}_{3}$, dried with $\mathrm{Na}_{2} \mathrm{SO}_{4}$ and evaporated in a vacuum. The residue was passed through a layer of silica using $\mathrm{CH}_{2} \mathrm{Cl}_{2}$ as the eluent. The solvent was evaporated to give $0.53 \mathrm{~g}(68 \%)$ of the title compound as a gray solid (m.p. 130-132 $\left.{ }^{\circ} \mathrm{C}\right) .{ }^{1} \mathrm{H}$ NMR $\delta_{\mathrm{H}}\left(300 \mathrm{MHz}, \mathrm{CD}_{2} \mathrm{Cl}_{2}\right) 7.76(2 \mathrm{H}, \mathrm{m}), 7.47(2 \mathrm{H}, \mathrm{m}), 6.58(2 \mathrm{H}, \mathrm{d}$, $J=2.4 \mathrm{~Hz}), 4.41(2 \mathrm{H}, \mathrm{t}, J=1.3 \mathrm{~Hz}), 2.53(6 \mathrm{H}, \mathrm{s}), 1.75(4 \mathrm{H}, \mathrm{m})$. 
${ }^{13} \mathrm{C} \mathrm{NMR} \delta_{\mathrm{C}}\left(75 \mathrm{MHz}, \mathrm{CD}_{2} \mathrm{Cl}_{2}\right) 169.96,137.94,135.36,126.91$, 126.64, 126.53, 121.82, 109.94, 32.28, 31.05, 27.65, 21.07. Anal. calcd for $\mathrm{C}_{22} \mathrm{H}_{19} \mathrm{NO}_{4}$ : C, 73.12; H, 5.30; N, 3.88; found: C, 72.65; H, 5.14; N, 3.47 .

\section{Porphyrin 12}

5,10-Diacetoxy-4,11-etheno- $2 H$-naphtho[2,3-f]isoindole (0.3 g, $0.83 \mathrm{mmol})$ was dissolved in $\mathrm{CH}_{2} \mathrm{Cl}_{2}(83 \mathrm{~mL})$ freshly distilled from $\mathrm{CaH}_{2}$, and benzaldehyde $(0.088 \mathrm{~g}, 0.83 \mathrm{mmol})$ was added. The mixture was stirred under nitrogen for $10 \mathrm{~min}$ in the dark at room temperature. $\mathrm{BF}_{3} \cdot \mathrm{Et}_{2} \mathrm{O}(10 \mu \mathrm{L}, 0.083 \mathrm{mmol})$ was added in one portion, and the mixture was stirred for an additional $2 \mathrm{~h}$. DDQ $(0.141 \mathrm{~g}, 0.62 \mathrm{mmol})$ was added followed by additional stirring for $2 \mathrm{~h}$. The resulting mixture was washed with aqueous $\mathrm{Na}_{2} \mathrm{SO}_{3}$, dried over $\mathrm{Na}_{2} \mathrm{SO}_{4}$ and concentrated in a vacuum. The residue was purified on a silica gel column (eluent $\mathrm{CH}_{2} \mathrm{Cl}_{2}$, then $\mathrm{CH}_{2} \mathrm{Cl}_{2}-\mathrm{HOAc}$, green band collected). Additional purification by recrystallization from $\mathrm{CH}_{2} \mathrm{Cl}_{2}-\mathrm{Et}_{2} \mathrm{O}$ delivered the title product $(67 \mathrm{mg}, 18 \%)$ as a dark-green powder. ${ }^{1} \mathrm{H}$ NMR $\delta_{\mathrm{H}}\left(300 \mathrm{MHz}, \mathrm{CD}_{2} \mathrm{Cl}_{2}-\mathrm{TFA}\right)$ 8.96-6.85 (36H, m), 4.74-4.17 (8H, m), 3.22-2.74 (24H, m), 2.15-1.84 (16H, m). ${ }^{13} \mathrm{C}$ NMR $\delta_{\mathrm{C}}\left(75 \mathrm{MHz}, \mathrm{CD}_{2} \mathrm{Cl}_{2}-\mathrm{TFA}\right) 170.26$, 137.89, 135.43, 134.96, 132.05, 127.12, 126.98, 126.66, 126.27, $121.71,120.45,110.42,32.59,31.16,27.34,21.45$. UV/vis $\left(\mathrm{CH}_{2} \mathrm{Cl}_{2}\right) \lambda_{\max }(\log \varepsilon): 434$ (5.2), 523 (4.21), 607 (3.93), 675 (3.84). MALDI-TOF: $\mathrm{m} / \mathrm{z}$ found 1791.61, calcd for $[\mathrm{M}+]$ $\mathrm{C}_{116} \mathrm{H}_{86} \mathrm{~N}_{4} \mathrm{O}_{16}$ 1791.60. Anal. calcd for $\mathrm{C}_{92} \mathrm{H}_{46} \mathrm{~N}_{4} \mathrm{O}_{8}$ : C, 77.75; $\mathrm{H}, 4.84, \mathrm{~N}, 3.13$; found: C, 78.58; H, 5.36; N, 3.41.

\section{$\mathrm{Ph}_{4}$ TAQP free base}

Porphyrin 12 (50 mg) was dissolved in THF (10 mL) and a solution of $\mathrm{KOH}(0.25 \mathrm{~g})$ in EtOH $(5 \mathrm{~mL})$ was added. The mixture was stirred at room temperature for $12 \mathrm{~h}$, then concentrated $\mathrm{HCl}(1 \mathrm{ml})$ was added and the solution was evaporated in a vacuum. The residue was washed several times with $\mathrm{CH}_{2} \mathrm{Cl}_{2}$ to separate soluble porphyrin from the inorganic solid, the resulting solution was dried with $\mathrm{Na}_{2} \mathrm{SO}_{4}$ and filtered. DDQ $(0.188 \mathrm{~g}$, $0.83 \mathrm{mmol}$ ) was then added and the mixture was stirred for $6 \mathrm{~h}$. The resulting mixture was washed with aqueous $\mathrm{Na}_{2} \mathrm{SO}_{3}$, dried over $\mathrm{Na}_{2} \mathrm{SO}_{4}$ and concentrated in a vacuum. The residual solid was heated in a vacuum oven at $200{ }^{\circ} \mathrm{C}$ for $4 \mathrm{~h}$. Then it was dissolved in $\mathrm{CH}_{2} \mathrm{Cl}_{2}$ and purified on a silica gel column (eluent $\mathrm{CH}_{2} \mathrm{Cl}_{2}$, then $\mathrm{CH}_{2} \mathrm{Cl}_{2}-\mathrm{THF}$, purple band collected). Additional purification by repetitive precipitation from $\mathrm{CH}_{2} \mathrm{Cl}_{2}-\mathrm{Et}_{2} \mathrm{O}$ delivered the title product $(24 \mathrm{mg}, 65 \%)$ as a purple powder. ${ }^{1} \mathrm{H}$ NMR $\delta_{\mathrm{H}}\left(500 \mathrm{MHz}, \mathrm{C}_{2} \mathrm{D}_{2} \mathrm{Cl}_{4}-\mathrm{TFA}\right) 8.69(8 \mathrm{H}$, m), $8.44(8 \mathrm{H}, \mathrm{s}), 8.38(4 \mathrm{H}, \mathrm{m}), 8.29-8.17(16 \mathrm{H}, \mathrm{m}), 7.83(8 \mathrm{H}$, m), 4.05 (4H, br. s). ${ }^{13} \mathrm{C}$ NMR $\delta_{\mathrm{C}}\left(125 \mathrm{MHz}, \mathrm{C}_{2} \mathrm{D}_{2} \mathrm{Cl}_{4}-\mathrm{TFA}\right)$ 181.73 , 142.53, 138.04, 135.86, 135.52, 134.56, 133.53, 133.12, 133.11, 130.39, 127.33, 124.70, 117.37. UV/vis $\left(\mathrm{CH}_{2} \mathrm{Cl}_{2}\right) \lambda_{\max }$ $(\log \varepsilon): 534$ (5.18), 642 (4.22), 699 (4.72), 752 (4.22). MALDITOF: $m / z$ found 1355.33, calcd for $[\mathrm{M}+] \mathrm{C}_{92} \mathrm{H}_{46} \mathrm{~N}_{4} \mathrm{O}_{8}$ 1355.33. Anal. calcd for $\mathrm{C}_{92} \mathrm{H}_{46} \mathrm{~N}_{4} \mathrm{O}_{8}$ : C, 82.75; H, 3.47, N, 4.20; found: C, 83.57; H, 3.98; N, 4.74.

Ph $\mathbf{4}$ TAQP-Pd was obtained in $75 \%$ yield after heating a mixture of the free-base porphyrin, excess $\mathrm{PdCl}_{2}(\mathrm{PhCN})_{2}(2 \mathrm{eq}$.) and $\mathrm{Et}_{3} \mathrm{~N}$ (10 eq.) in benzonitrile at $160{ }^{\circ} \mathrm{C}$ for $0.5-3 \mathrm{~h}$ (control by UV-Vis spectroscopy), with subsequent filtration through a layer of silica (eluent $\mathrm{CH}_{2} \mathrm{Cl}_{2}$ ) and evaporation of the filtrate. UV/vis $\left(\mathrm{CH}_{2} \mathrm{Cl}_{2}\right) \lambda_{\max }(\log \varepsilon): 501$ (5.05), 629 (4.11), 686 (4.97). MALDI-TOF: $\mathrm{m} / \mathrm{z}$ found 1439.2361, calcd for $[\mathrm{M}+]$ $\mathrm{C}_{92} \mathrm{H}_{44} \mathrm{~N}_{4} \mathrm{O}_{8} \mathrm{Pd}$ 1439.22.

$\mathbf{P h}_{\mathbf{4}}$ TAQP-Zn was obtained in $90 \%$ yield after the treatment of a free-base in THF with an excess of $\mathrm{Zn}(\mathrm{OAc})_{2} \cdot 2 \mathrm{H}_{2} \mathrm{O}$, followed by subsequent precipitation with $\mathrm{MeOH}$, filtration and drying in a vacuum. UV/vis $\left(\mathrm{CH}_{2} \mathrm{Cl}_{2}\right) \lambda_{\max }(\log \varepsilon): 552$ (5.12), 677 (4.35), 727 (4.84). MALDI-TOF: $m / z$ found 1397.24, calcd for $[\mathrm{M}+] \mathrm{C}_{92} \mathrm{H}_{44} \mathrm{~N}_{4} \mathrm{O}_{8} \mathrm{Zn}$ 1397.24.

\section{Acknowledgements}

M.A.F. acknowledges POLINNOVA project (FP7-REGPOT-20122013-1) for the financial support. Financial support from the Bulgarian Science Fund (DFNI E 02/11 - SunStore-project) and the European Commission FCFP FRIAS COFUND Fellowship Programme (FP7-MCA-609305) for S.B. are highly appreciated.

\section{Notes and references}

1 (a) S. M. Borisov, G. Nuss, W. Haas, R. Saf, M. Schmuck and I. Kilmant, J. Photochem. Photobiol., A, 2009, 201, 128; (b) C. Wohnhaas, V. Mailänder, M. Dröge, M. A. Filatov, D. Busko, Y. Avlasevich, S. Baluschev, T. Miteva, K. Landfester and A. Turshatov, Macromol. Biosci., 2013, 13, 1422; (c) R. Kumar, T. Y. Ohulchanskyy, I. Roy, S. K. Gupta, C. Borek, M. E. Thompson and P. N. Prasad, ACS Appl. Mater. Interfaces, 2009, 1, 1474; (d) M. D. Perez, C. Borek, P. I. Djurovich, E. I. Mayo, R. R. Lunt, S. R. Forrest and M. E. Thompson, Adv. Mater., 2009, 21, 1517; (e) T. N. Singh-Rachford, A. Haefele, R. Ziessel and F. N. Castellano, J. Am. Chem. Soc., 2008, 130, 16164; (f) L. H. Hutter, B. J. Müller, K. Koren, S. M. Borisov and I. Klimant, J. Mater. Chem. C, 2014, 2, 7589; (g) S. M. Borisov, C. Larndorfer and I. Klimant, Adv. Funct. Mater., 2012, 22, 4360; (h) T. V. Esipova, A. Karagodov, J. Miller, D. F. Wilson, T. M. Busch and S. A. Vinogradov, Anal. Chem., 2011, 83, 8756; (i) B. J. Muller, T. Burger, S. M. Borisov and I. Klimant, Sens. Actuators, B, 2015, 216, 527.

2 (a) S. Baluschev, T. Miteva, V. Yakutkin, Y. S. Avlasevich, K. Müllen, G. Nelles, S. Chernov, S. Aleshchenkov, A. Cheprakov, A. Yasuda and G. Wegner, Angew. Chem., Int. Ed., 2007, 46, 7693; (b) C. Wohnhaas, K. Friedemann, D. Busko, K. Landfester, S. Baluschev, D. Crespy and A. Turshatov, ACS Macro Lett., 2013, 2, 446; (c) A. J. Svagan, D. Busko, Y. Avlasevich, G. Glasser, S. Baluschev and K. Landfester, ACS Nano, 2014, 8, 8198.

3 (a) O. S. Finikova, S. Y. Chernov, A. V. Cheprakov, M. A. Filatov, S. A. Vinogradov and I. P. Beletskaya, Dokl. Chem., 2003, 391, 222; (b) M. A. Filatov, A. V. Cheprakov 
and I. P. Beletskaya, Eur. J. Org. Chem., 2007, 3468; (c) M. A. Filatov, A. Y. Lebedev, S. A. Vinogradov and A. V. Cheprakov, J. Org. Chem., 2008, 73, 4175.

4 (a) O. S. Finikova, S. E. Aleshchenkov, R. P. Brinas, A. V. Cheprakov, P. J. Carroll and S. A. Vinogradov, J. Org. Chem., 2005, 70, 4617; (b) M. A. Filatov and A. V. Cheprakov, Tetrahedron, 2011, 67, 3559; (c) E. R. Ranyuk, M. A. Filatov, A. D. Averin, A. V. Cheprakov and I. P. Beletskaya, Synthesis, 2012, 393; (d) J. M. Manley, T. J. Roper and T. D. Lash, J. Org. Chem., 2005, 70, 874; (e) X.-Z. Jiang, C.-X. Cai, J.-T. Liu and H. Uno, Org. Biomol. Chem., 2012, 10, 3110.

5 V. Gandhi, M. L. Thompson and T. D. Lash, Tetrahedron, 2010, 66, 1787.

6 K. Kurotobi, K. S. Kim, S. B. Noh, D. Kim and A. Osuka, Angew. Chem., Int. Ed., 2006, 45, 3944.

7 (a) M. A. Filatov, S. Baluschev, I. Z. Ilieva, V. Enkelmann, T. Miteva, K. Landfester, S. E. Aleshchenkov and A. V. Cheprakov, J. Org. Chem., 2012, 77, 11119; (b) H. Yamada, D. Kuzuhara, T. Takahashi, Y. Shirnizu, K. Uota, T. Okujima, H. Uno and N. Ono, Org. Lett., 2008, 10, 2947.

8 H. Boedigheimer, G. M. Ferrence and T. D. Lash, J. Org. Chem., 2010, 75, 2518.

9 (a) A. V. Cheprakov, in The Synthesis of $\pi$-Extended Porphyrins. Handbook of Porphyrin Science, ed. K. M. Kadish, K. M. Smith and R. Guilard, World Scientific, Singapore, 2011, vol. 13; (b) N. Ono, H. Yamada and T. Okujima, in Synthesis of Porphyrins Fused with Aromatic Rings. Handbook of Porphyrin Science, ed. K. M. Kadish, K. M. Smith and R. Guilard, World Scientific, Singapore, 2011, vol. 2.

10 S. Banala, T. Ruhl, K. Wurst and B. Krautler, Angew. Chem., Int. Ed., 2009, 48, 599.

11 D. Qi and J. Jiang, Int. J. Quantum Chem., 2013, 113, 2605.

12 H. Tributsch, Electrochim. Acta, 2007, 2302.

13 (a) S. Banala, K. Wurst and B. Krautler, J. Porphyrins Phthalocyanines, 2014, 18, 115; (b) S. Banala, R. G. Huber, T. Müller, M. Fechtel, K. R. Liedl and B. Kräutler, Chem. Commun., 2012, 48, 4359; (c) B. Kräutler, C. S. Sheehan and A. Rieder, Helv. Chim. Acta, 2000, 83, 583.
14 (a) R. Bonnet and R. F. C. Brown, J. Chem. Soc., Chem. Commun., 1972, 393; (b) J. Bornstein, J. E. Shields and D. E. Remy, J. Chem. Soc., Chem. Commun., 1972, 1149.

15 A. V. Cheprakov and M. A. Filatov, J. Porphyrins Phthalocyanines, 2009, 13, 291.

16 (a) S. Ito, N. Ochi, T. Murashima, N. Ono and H. Uno, Chem. Commun., 2000, 893; (b) T. Okujima, T. Kikkawa, H. Nakano, H. Kubota, N. Fukugami, N. Ono, H. Yamada and H. Uno, Chem. - Eur. J., 2012, 18, 12854; (c) Y. Tomimori, T. Okujima, T. Yano, S. Mori, N. Ono, H. Yamada and H. Uno, Tetrahedron, 2011, 67, 3187; (d) H. Uno, H. Uoyama, C. Chenxin, H. Tahara, Y. Shimizu, H. Hagiwara, Y. Hanasaki, H. Yamada and T. Okujima, Heterocycles, 2010, 80; (e) H. Uoyama, T. Takiue, K. Tominaga, N. Ono and H. Uno, J. Porphyrins Phthalocyanines, 2009, 13, 122.

17 (a) D. P. Arnold, L. Burgess-Dean, J. Hubbard and M. Abdur Rahman, Aust. J. Chem., 1994, 969; (b) Y. Abel, E. Haake, G. Haake, W. Schmidt, D. Struve, A. Walter and F. P. Montforts, Helv. Chim. Acta, 1998, 81, 1978.

18 B. P. Bandgar, L. S. Uppalla, A. D. Sagar and V. S. Sadavarte, Tetrahedron Lett., 2001, 42, 1163.

19 J. J. Stromich, A. K. Weber, Y. R. Mirzaei, M. D. Caldwell and D. E. Lewis, Bioorg. Med. Chem. Lett., 2010, 20, 1928.

20 O. S. Finikova, A. V. Cheprakov, I. P. Beletskaya, P. J. Carroll and S. A. Vinogradov, J. Org. Chem., 2004, 69, 522.

$21 \mathrm{H}$. Pines and W. M. Stalick, Base-catalyzed reactions of hydrocarbons and related compounds, Academic Press, New York, 1977, p. 483.

22 J. S. Lindsey, I. C. Schreiman, H. C. Hsu, P. C. Kearny and A. M. Marguerettaz, J. Org. Chem., 1987, 52, 827.

23 M. A. Filatov, E. Heinrich, D. Busko, I. Z. Ilieva, K. Landfester and S. Baluschev, Phys. Chem. Chem. Phys., 2015, 17, 6501.

24 B. H. Novak and T. D. Lash, J. Org. Chem., 1998, 63, 3998.

25 P. G. Seybold and M. Gouterman, J. Mol. Spectrosc., 1969, 31, 1.

26 S. R. Angle and W. Yang, J. Am. Chem. Soc., 1990, 112, 4524.

27 P. B. Hopkins and P. L. Fuchs, J. Org. Chem., 1978, 43, 1208. 